УДК 636.223.083.3

(C) 2017

\author{
Колісник О. І., кандидат сільськогосподарських наук, \\ директор ПП «Агро-Новоселівка 2009» Харківської області, \\ Прудніков В. Г., доктор сільськогосподарських наук, професор, \\ Криворучко Ю. І., кандидат сільськогосподарських наук \\ Харківська державна зооветеринарна академія
}

Нагорний С. А., кандидат сільськогосподарських наук

Харківський національний технічний університет сільського господарства ім. Петра Василенка

\title{
ТЕХНОЛОГІЧНІ ОСОБЛИВОСТІ УТРИМАННЯ М'ЯСНОЇ ХУДОБИ АБЕРДИН-АНГУСЬКОЇ ПОРОДИ В ЗИМОВИЙ ПЕРІОД НА ВІДКРИТИХ МАЙДАНЧИКАХ
}

\section{Рецензент - доктор сільськогосподарських наук, професор А. М. Хохлов}

Розглянуто питання необхідності коригування деяких параметрів технології м'ясного скотарства 3 урахуванням впливу природно-кліматичних умов під час утримання худоби в зимовий період на вигульнокормових майданчиках без використання капітальних приміщень. Абердин-ангуська порода добре пристосована до впливу низьких температур, але в зимовий період опади у вигляді дошу та мокрого снігу з холодним вологим вітром, негативно впливають на інтенсивність росту тварин. Для запобігання зменшення продуктивності худоби необхідно збільшувати внесення кількості солом'яної підстилки на одну голову до 7 кг за добу та підвищувати енергетичну поживність раціону за рахунок концентратів. За критично низьких температур більи доиільно збільшувати в раціоні кількість грубих і об'ємистих кормів та замість силосу краще використовувати сінаж з меншою вологістю, який більи технологічний до згодовування.

Ключові слова: технологія, м'ясне скотарство, худоба, абердин-ангуська порода, зимовий період, інтенсивність росту, природно-кліматичні умови.

Постановка проблеми. М'ясне скотарство України переживає не найкращі часи. Навіть незначна кількість господарств, які знаходяться в різних природно-кліматичних зонах країни та спеціалізуються на вирощуванні м'ясної худоби, не мають єдиної технології іiі утримання в зимовий період. При цьому використовують як капітальні приміщення, так і споруди полегшеного типу. Вирощування худоби без використання приміщень на вигульно-кормових майданчиках майже не застосовується, а навіть якщо і вирощують в аналогічних умовах, то не завжди існує єдина думка стосовно оптимальних технологічних параметрів, які б забезпечували стабільні високі прирости живої маси тварин, залежно від різких змін параметрів навколишнього середовища, низьку собівартість виробленої продукції за мінімальних витратах праці, енергетичних i матеріальних ресурсів. Неоднозначність вирішення даного питання і стало метою наших досліджень.

Аналіз основних досліджень і публікацій, у яких започатковано розв'язання проблеми. Однією з привілегій під час вирощування абердинів $\epsilon$ спроможність без втрати продуктивності переносити навіть дуже низькі температури повітря. Сприяє цьому густий волосяний покрив та значний жировий прошарок, який також відіграє функцію терморегуляції тварин у холодний період. У випадку зниження температури навколишнього середовища в організмі тварин домінує процес накопичення жиру. Добре розвинений волосяний покрив та підшкірний жир запобігає переохолодженню організму тварин, а також оберігає його від атмосферних опадів та холодних зимових вітрів.

У абердин-ангусів, які утримуються за відсутністю приміщень, поживні речовини в зимовий період, у першу чергу, використовуються організмом на жировідкладення в якості захисного прошарку. Тварини можуть відпочивати, лежачи на мерзлому грунті та снігу [1-6]. Висока адаптаційна здатність абердин-ангусів дає можливість без значних втрат живої маси в зимовий період отримувати яловичину з низькою собівартістю і з високою якістю.

Мета дослідження - вивчення питання необхідності коригування деяких параметрів технології м'ясного скотарства з урахуванням впливу природно-кліматичних умов під час утримання худоби абердин-ангуської породи в зимовий період на вигульно-кормових майданчиках без використання капітальних приміщень. 


\section{СІЛЬСЬКЕ ГОСПОДАРСТВО. ТВАРИННИЦТВО}

Матеріали та методика досліджень. Дослідження проводили за даними держметеослужби за період 2007-2016 роки та зоотехнічного обліку ПП «Агро-Новоселівка 2009» Нововодолазького району, Харківської області. Було відібрано і проаналізовано практично два однакових зимових періоди (2009-2010 та 2014-2015 роки) за динамікою температур та кількістю опадів у зимовий період. Різниця була лише у видах опадів - снігу чи дощу та наявності вітру. Порівнюючи вплив цих факторів та динаміку живої маси молодняку під час утримання в зимовий період, були внесені деякі зміни в параметри технології для запобігання втрати інтенсивності росту та отримання стабільних приростів живої маси.

Результати дослідження. В господарстві, в разі утримання м'ясної худоби, застосовують цілорічну стійлово-пасовищну систему утримання. Тварини в зимовий період знаходяться на вигульно-кормових майданчиках безприв'язно на довгонезмінній солом'яній підстилці за відсутності приміщень. Майданчики поділені на секції та обладнані годівницями і напувалками у вигляді корит. Секції, для утримання корів $з$ телятами, обладнані навісами. Для привчання те- лят до поїдання грубих, соковитих та концкормів секції обладнують невисокими загонами 3 лазами, куди легко проходить теля, а корова потрапити змоги немає. Загони обладнані годівницями для сіна, сінажу, концентрованих кормів. Телята мають вільний доступ до цих кормів. Суха підстилка в секціях та відсутність протягів - головні умови для запобігання хвороб тварин. У таких умовах телята легко переносять низькі температури, а середньодобові прирости коливаються в межах 850-1000 г.

Жива маса телят після відлучення в 7 міс. становить 195-210 кг. Цей період придає, як правило, на жовтень місяць кожного року. Після відлучення відгодовують молодняк до 14-16-місячного віку.

Слід зазначити, що головною передумовою утримання худоби в зимовий період за відсутністю приміщень був початковий досвід ведення м'ясного скотарства в господарстві, під час утримання молодняку абердин-ангуської породи в приміщеннях. Відомо, що підвищення температури в приміщенні призводить до порушення цілої низки функціонального статусу організму, що сприяє перегріву тіла та втраті продуктивності тварин.

\section{1. Динаміка живої маси молодняку абердин-ангуської породи в зимовий період залежно від температури повітря та опадів}

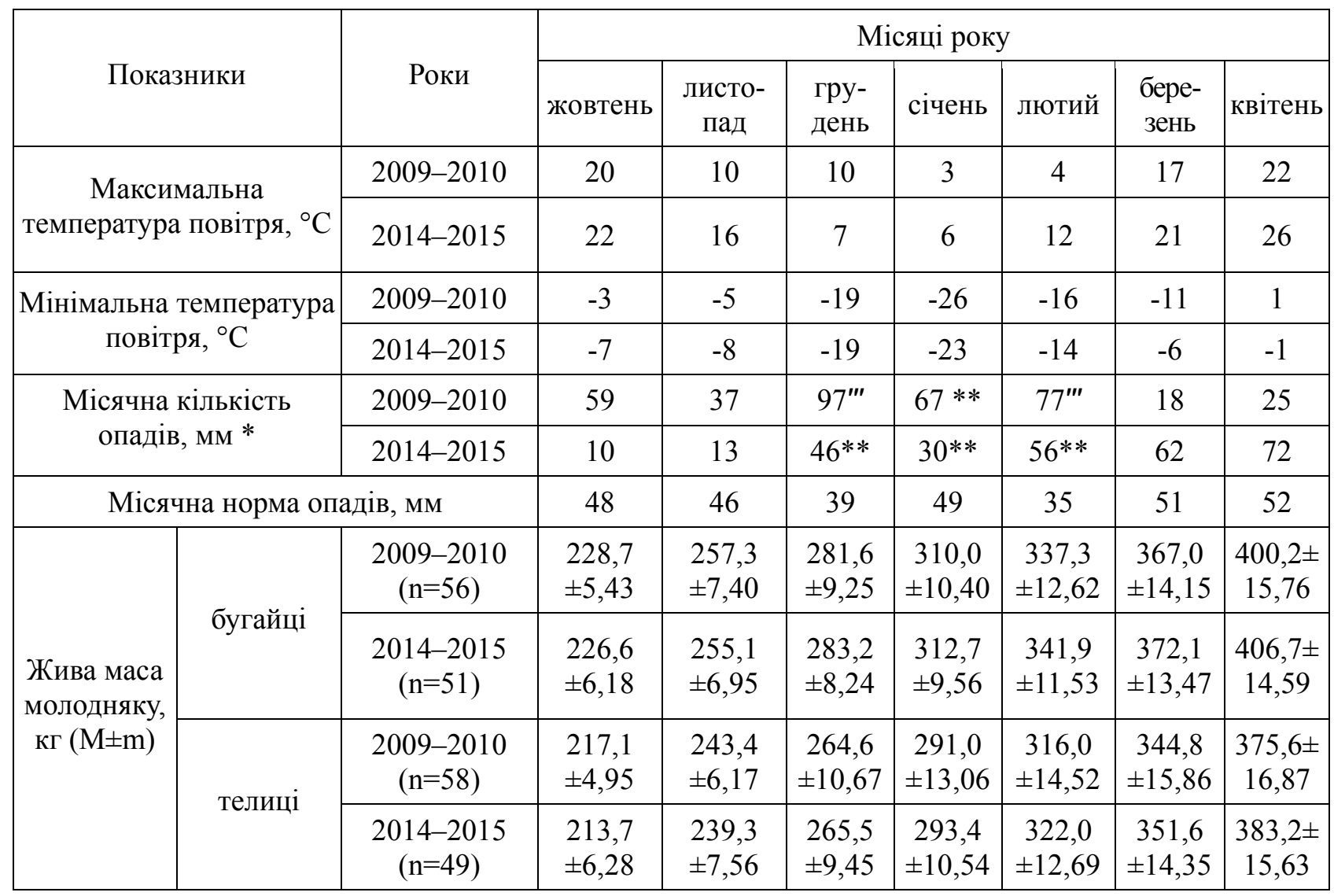

*Примітка: ** - опади у вигляді снігу; "' - опади у вигляді дощу та дощу з мокрим снігом. 
Як зазначає І. Л. Семак [7], в умовах зимової відгодівлі нормальною температурою в приміщенні, де утримується худоба, прийнято вважати $+5-10{ }^{\circ} \mathrm{C}$. У разі підвищення температури тварини почувають себе некомфортно, стають млявими, втрачають апетит. Механізм терморегуляції молодняка підсилює процеси потовиділення, в результаті чого шкіряний покрив стає вологим, а організм тварин вразливим до простудних захворювань.

Під час аналізу коливань температур та кількості опадів у період зимового утримання за 2007-2016 роки було встановлено, що найбільш спільними за цими показниками були 2009-2010 та 2014-2015 роки. Проте відмінність була у видах опадів - снігу, мокрого снігу та дощу.

Аналізуючи дані таблиці 1, зазначимо, що в зимовий період кількість опадів була майже в усі місяці більше місячної норми, окрім січня 2015 року. Температура повітря в ці періоди була майже однаковою зі значними коливаннями від $+10-12{ }^{\circ} \mathrm{C}$ до $-23-26{ }^{\circ} \mathrm{C}$.

За період 3 жовтня по грудень місяць жива маса як бугайців, так і телиць за аналізуємими роками була майже на одному рівні. Тварини абердин-ангуської породи добре пристосовані до впливу низьких температур зовнішнього середовища, однак втручання західних та північносхідних холодних та вологих вітрів та опадів у вигляді дощу, або дощу з мокрим снігом, мають негативний характер, на організм тварин i, як наслідок, зменшується інтенсивність їх росту в період грудня та лютого 2009-2010 років, порівнюючи 3 2014-2015, на 0,6-1,3\% у бугайців та на $1,8 \%$ у телиць. Однак в подальшому, за відсутності опадів у вигляді дощу, спостерігалася стабільна тенденція щодо збільшення живої маси тварин. Так, у 14 міс. жива маса телиць становила 375,6 кг, а бугайців - 400,2 кг, яка незначно поступалася ровесникам 2014-2015 років.

Аналіз середньодобових приростів (табл. 2) молодняку абердин-ангуської породи показав, що після відлучення від корів у жовтні місяці, вони були на невисокому рівні 610-643,3 г і суттєвої різниці по рокам не спостерігалось. У наступний місяць прирости збільшились до 853,3-953,3 г. Під впливом перепаду температур від +10 до $-19^{\circ} \mathrm{C}$ та значних опадів у вигляді дощу та мокрого снігу в грудні місяці 2009 року, середньодобові прирости становили у телиць 706,6 г, а бугайців 810 г, що менше за попередній місяць відповідно на 170,1 г $(19,4 \%)$ та 143,3 г (15\%). Зниження температури повітря та опади у вигляді снігу не вплинули на середньодобові прирости молодняку в грудні 2014 року, і були на достатньо високому рівні і становили $873,3-936,6$ г.

\section{2. Прирости молодняку під час утримання в зимовий період}

\begin{tabular}{|c|c|c|c|c|c|c|c|c|c|}
\hline \multirow{2}{*}{\multicolumn{2}{|c|}{ Показники }} & \multirow{3}{*}{$\begin{array}{c}\text { Роки } \\
\begin{array}{c}2009-2010 \\
(\mathrm{n}=56)\end{array}\end{array}$} & \multicolumn{7}{|c|}{ Місяці року } \\
\hline & & & \multirow{2}{*}{$\begin{array}{c}\text { жовтень } \\
19,1\end{array}$} & \multirow{2}{*}{$\begin{array}{c}\text { листопад } \\
28,6\end{array}$} & \multirow{2}{*}{\begin{tabular}{c|} 
грудень \\
$\mathbf{2 4 , 3}$
\end{tabular}} & \multirow{2}{*}{\begin{tabular}{|c|} 
січень \\
$\mathbf{2 8 , 4}$ \\
\end{tabular}} & \multirow{2}{*}{$\begin{array}{c}\text { лютий } \\
\mathbf{2 7 , 3}\end{array}$} & \multirow{2}{*}{$\begin{array}{c}\text { березень } \\
29,7\end{array}$} & \multirow{2}{*}{$\begin{array}{c}\text { квітень } \\
33,2\end{array}$} \\
\hline \multirow{4}{*}{$\begin{array}{c}\text { Абсолютний } \\
\text { приріст, } \\
\text { кг }\end{array}$} & \multirow{2}{*}{ бугайці } & & & & & & & & \\
\hline & & $\begin{array}{c}2014-2015 \\
(\mathrm{n}=51)\end{array}$ & 19,3 & 28,5 & 28,1 & 29,5 & 29,2 & 30,2 & 34,6 \\
\hline & \multirow{2}{*}{ телиці } & $\begin{array}{c}2009-2010 \\
(\mathrm{n}=58)\end{array}$ & 18,5 & 26,3 & 21,2 & 26,4 & 25,0 & 28,8 & 30,8 \\
\hline & & $\begin{array}{c}2014-2015 \\
\quad(\mathrm{n}=49)\end{array}$ & 18,3 & 25,6 & 26,2 & 27,9 & 28,6 & 29,6 & 31,6 \\
\hline \multirow{4}{*}{$\begin{array}{c}\text { Середньо- } \\
\text { добовий } \\
\text { приріст, г }\end{array}$} & \multirow{2}{*}{ бугайці } & $\begin{array}{c}2009-2010 \\
(\mathrm{n}=56)\end{array}$ & 636,6 & 953,3 & 810,0 & 946,7 & 910,0 & 990,0 & 1106,7 \\
\hline & & $\begin{array}{c}2014-2015 \\
\quad(n=51)\end{array}$ & 643,3 & 950,0 & 936,6 & 983,3 & 973,3 & 1006,7 & 1153,3 \\
\hline & \multirow{2}{*}{ телиці } & $\begin{array}{c}2009-2010 \\
(\mathrm{n}=58)\end{array}$ & 616,7 & 876,7 & 706,6 & 880,0 & 833,0 & 960,0 & 1026,7 \\
\hline & & $\begin{array}{c}2014-2015 \\
(\mathrm{n}=49)\end{array}$ & 610,0 & 853,3 & 873,3 & 930,0 & 953,3 & 986,6 & 1053,3 \\
\hline
\end{tabular}


СІЛЬСЬКЕ ГОСПОДАРСТВО. ТВАРИННИЦТВО

\section{3. Норми годівлі молодняку та внесення солом'яної підстилки в зимовий період}

\begin{tabular}{|c|c|c|c|c|c|c|c|c|}
\hline \multirow{2}{*}{ Показники } & \multirow{2}{*}{ Роки } & \multicolumn{7}{|c|}{ Місяці року } \\
\hline & & жовтень & листопад & грудень & січень & лютий & березень & квітень \\
\hline \multirow{2}{*}{$\begin{array}{l}\text { Мінімальна температу- } \\
\text { ра повітря, }{ }^{\circ} \mathrm{C}\end{array}$} & 2009-2010 & -3 & -5 & -19 & -26 & -16 & -11 & 1 \\
\hline & $2014-2015$ & -7 & -8 & -19 & -23 & -14 & -6 & -1 \\
\hline \multirow{2}{*}{$\begin{array}{l}\text { Місячна кількість опа- } \\
\text { дів, мм * }\end{array}$} & 2009-2010 & 59 & 37 & $97 " \prime$ & $67 * *$ & 77"' & 18 & 25 \\
\hline & 2014-2015 & 10 & 13 & $46^{* *}$ & $30 * *$ & $56^{* *}$ & 62 & 72 \\
\hline \multirow{2}{*}{$\begin{array}{l}\text { Добова норма: } \\
\text { підстилки, кг/гол }\end{array}$} & 2009-2010 & 3 & 3 & 7 & 5 & 7 & 3 & 3 \\
\hline & 2014-2015 & \multicolumn{7}{|c|}{3} \\
\hline \multirow{2}{*}{ силосу (сінажу), кг/гол } & 2009-2010 & 15 & 20 & 25 & 20 & 25 & 20 & 20 \\
\hline & 2014-2015 & 15 & 20 & 20 & 20 & 20 & 20 & 20 \\
\hline \multirow{2}{*}{ сіна, кг/гол } & 2009-2010 & 3 & 4 & 7 & 7 & 7 & 5 & 5 \\
\hline & 2014-2015 & 3 & 4 & 5 & 7 & 5 & 5 & 5 \\
\hline \multirow{2}{*}{ концентратів, кг/гол } & 2009-2010 & 1 & 1,5 & 2 & 3 & 2 & 2 & 2 \\
\hline & 2014-2015 & 1 & 1,5 & 2 & 3 & 2 & 2 & 2 \\
\hline
\end{tabular}

За рахунок своєчасного збільшення внесення солом'яної підстилки в лютому місяці 2010 року, негативний вплив температури повітря і опадів у вигляді дощу нівелювався і молодняк мав незначне зменшення приростів на 36-47 г. Це ще раз свідчить про те, що абердин-ангуська порода має високу адаптаційну здатність. У наступні місяці, за комфортних умов утримання, прирости живої маси телиць і бугайців зросли до 1026,7-1106,7 г і були майже на одному рівні $з$ ровесниками 2014-2015 року.

Сухе лігво є одним з необхідних елементів технології утримання худоби взимку. Для цього в секціях формують глинобитні кургани висотою 11,5 м, шириною $10-15$ м 3 розрахунку 3-5 м² на одну голову з товстим шаром солом'яної підстилки до 30-40 см. За рахунок ферментаційних процесів в підстилці, яке супроводжується виділенням тепла, вона стає теплою і дає тваринам можливість зігріватися. Для вітрозахисту секції обладнані огорожею.

Низка фахівців [6] рекомендують взимку, під час сильних опадів, вносити 125 кг соломи на тиждень на одну голову. В наших дослідженнях (табл. 3) було встановлено, що для комфортного утримання абердин-ангусів у таких умовах достатньо було на одну голову 7 кг підстилки на добу (50 кг на тиждень). Також у такі періоди, для запобігання спаду продуктивності тварин, у випадку зниження температури до $-20^{\circ} \mathrm{C}$, додатково згодовують 1 кг концентратів на кожне зменшення температури на $-5{ }^{\circ} \mathrm{C}$.

Критична температура замерзання силосу $-20^{\circ} \mathrm{C}$.
У такі періоди оператори в годівницях проводять механічне ворушіння кормової маси з метою пошкодження на ній льодяної скоринки та здійснення ефекту свіжерозданого корму. В разі зменшення температури повітря навколишнього середовища нижче $-20^{\circ} \mathrm{C}$, в раціоні силос замінюють на сінаж, температура замерзання якого від -23 до $-26{ }^{\circ} \mathrm{C}$, в результаті чого тварини значно краще його споживають. У таких умовах збільшують кількість сінажу в раціоні до 25 кг на одну голову, сіна - до 7 кг.

\section{Висновки:}

1. Абердин-ангуська порода має високу адаптаційну здатність та пристосованість до впливу низьких температур навколишнього середовища. Так, інтенсивність росту молодняка під впливом критичних температур і опадів у вигляді дощу і мокрого снігу хоча i знизилась, але незначно на $0,6-1,3 \%$ у бугайців і на $1,8 \%$ у телиць за період грудня-лютого 2009-2010 року, порівняно $з$ 2014-2015 роком.

2. Для нівелювання впливу критично низьких температур, опадів у вигляді дощу та холодного вітру доцільно створити більш щадні умови утримання, шляхом внесення солом'яної підстилки до 7 кг на одну голову, замінити силос на сінаж та збільшити його кількість у раціоні до 25 кг на одну голову, сіна - до 7 кг, а також збільшити в раціоні концентратів на 1 кг на голову за добу в разі зменшення температури нижче $-20{ }^{\circ} \mathrm{C}$ на кожні $-5{ }^{\circ} \mathrm{C}$. Це дасть змогу отримувати стабільні прирости живої маси тварин абердин-ангуської породи. 


\section{БІБЛІОГРАФІЯ}

1. Aberdeen Angus [Електронний ресурс]. Режим доступу : http:// www.wow.com/wiki/ Angus_cattles_chn $=74 \& s \_p t=$ source $2 \& s \_g l=U S \& v$ $\mathrm{t}=$ content.

2. Описание коров породы ангус [Електронний ресурс]. - Режим доступу : https://fermok. ru/2017/08/opisanie-korov-porodyi-angus/.

3. Абердин-ангусская порода коров [Електроний ресурс]. - Режим доступу : https://agronomu. com/bok/672-aberdin-angusskaya-porodakorov.html.

4. Андриенко В. Ф. Влияние резкой смены температуры среды на физиологические функции телят / В. Ф. Андриенко // Использование биологических закономерностей в повышении продуктивности с.-х. животных : материалы конференции зоотехнического факультета. Краснодар, 1971. - С. 29-34.

5. Стратегія розвитку м'ясного скотарства в Україні у контексті національної продовольчої безпеки / [Зубець М. В., Буркат В. П., Гузєв I. В. та ін.]. - К. : Аграрна наука. - 2005. - 176 с.

6. Угнівенко А. М. Наукові основи розвитку м'ясного скотарства в Україні / А. М.Угнівенко, С. М. Петренко, Д. К. Носевич, Ю. І. Токар // Монографія. - К. : Компринт. - 2016. - 330 с.

7. Семак І. Л. Інтенсивність відгодівлі худоби / І. Л. Семак // Урожай. - К., 1965. - С. 61-63. 